\section{Natural Mulches Are Not Very Effective for Weed Control in Onions}

\author{
George E. Boyhan ${ }^{1}$, Ray Hicks ${ }^{2}$, and C. Randell Hill ${ }^{3}$
}

AdDitional Index words. Allium cepa, sustainable, Vidalia, short-day, nonstorage, certified organic

SUMMARY. This study was undertaken to evaluate natural mulches for weed control in organic onion (Allium cepa) production where current practices rely on hand-weeding or plastic mulch. Three experiments were conducted over 2 years, with two experiments conducted on-farm in different years and one experiment conducted on-station. Treatments consisted of hand-weeding or mulches of wheat (Triticum aestivum) or oat (Avena sativa) straw, bermudagrass hay (Cynodon dactylon), compost, and needles of slash pine (Pinus elliottii) and longleaf pine ( $P$. palustris). All of the mulches with the exception of compost tended to lodge in the onion tops due to their close spacing. Wheat straw and bermudagrass hay reduced plant stand and yield. Compost settled well around the onion plants and initially smothered weeds, but over time the compost treatment became very weedy. Pine needle mulch (referred to as pine straw in the southeastern U.S.) showed the most promise with less stand loss or yield reduction, but did tend to lodge in the tops. None of these mulches were acceptable compared to hand-weeding.

I n southeastern Georgia, mild short-day onions are produced under the Vidalia trademark (State of Georgia, Atlanta). These onions are known throughout North America for their exceptionally mild flavor and therefore they command a premium in the marketplace (Boyhan and Torrance, 2002). Their popularity has spurred the development of a small market for organically produced Vidalia onions.

Organic production practices for onions have been evaluated in a number of studies. These studies have investigated weed control, variety selection, disease control, fertilization practices, and cultural practices (Bourdôt et al., 2004; Hellwig and Buczak, 1973; Mihelic and Jakse, 2001; Ozer et al., 2002; Piazza et al., 2003). In one study of weed control in onions, brushing and thermal weed control (brushing uses a brush to physically control weeds and thermal uses a propane flame to control weeds) were compared, with the conclusion that brushing reduced yields compared to thermal weed

${ }^{1}$ Department of Horticulture, University of Georgia, East Georgia Extension Center, P.O. Box 8112, Statesboro, GA 30460.

${ }^{2}$ Screven County Cooperative Extension Service, University of Georgia, 321 Rocky Ford Road, Sylvania, GA 30467.

${ }^{3}$ Vidalia Onion and Vegetable Research Center, University of Georgia, 8163 Highway 178, Lyons, GA 30436. control (Juncker et al., 1993). Weeds increased in carrot (Daucus carota var. sativus) production when onions were part of the rotation compared to barley (Hordeum vulgare), indicating onion's poor competition with weeds and allelopathic effects of barley (Leroux et al., 1996). Weed seed banks decreased in these experiments when barley was part of the carrot/onion/barley rotation with the sequence of the rotation not being a factor (Benoit et al., 2003).

Examination of the soil weed seed bank in onions showed there was no difference in the number of weed seed between maintaining weed-free plots compared to weeding only once at either 4,5 , or 6 weeks post $50 \%$ emergence. Unweeded plots had between 2 - and 70 -fold increase in soil weed seed over the 4 years of the study (Bond et al., 1998). In the Philippines, onion weed control and yield increased by burning $30 \mathrm{~cm}$ of rice (Oryza sativa) hulls and incorporating the ash before onion planting (Gergon et al., 2001).

Onions are considered poor competitors with weeds for several reasons, including their small size and slow growth at emergence as well as their upright habit, which does not exclude light from other plants (Brewster, 1994). In commercial onion production in the southeastern U.S., effective weed control is available through the use of several herbicides, the most important of which are DCPA, pendimethalin, and oxyflurofen (Culpepper, 2004). In organic production, however, the use of chemical herbicides is prohibited, making the control of weeds more difficult. Under the $\mathrm{Na}$ tional Organic Program (NOP) rules, the use of plastic mulch is allowed for weed control as long as efforts are made to reuse the material and it is removed from the field at the end of production. Many organic growers would like to find a more sustainable alternative to the use of nonbiodegradable plastic. This study was therefore undertaken to evaluate several natural mulches and their effectiveness in controlling weeds in onions.

\section{Materials and methods}

Our study consisted of 2-year onfarm trials in Screven County, Ga., and a 1-year on-station trial at the Vidalia Onion and Vegetable Research Center (VOVRC), Lyons, Ga.

SCreven County trials. Organically produced transplants of 'Pegasus' onions were transplanted by hand on 28 Dec. 2002 at an on-farm location in Screven County, Ga. (lat. $32^{\circ} 37^{\prime} \mathrm{N}$, long. $\left.81^{\circ} 3 \mathrm{I}^{\prime} \mathrm{W}\right)$. Onion transplants with $50 \%$ of their tops removed were planted on 4-inch-high beds formed $6 \mathrm{ft}$ on-centers with four rows per bed. Onion transplants were planted with 5.5-inch in-row and 12 -inch between-row spacing. The soil was a Grady sandy loam with a top horizon of peat moss (clayey, kaolinitic, thermic Typic Paleaquults). Fertilization consisted of applications of soybean meal, fish emulsion, blood meal, and locally produced compost to supply the equivalent of $150 \mathrm{lb} /$ acre nitrogen. One-third was applied preplant and incorporated with an additional

\begin{tabular}{llll}
\hline $\begin{array}{l}\text { Units } \\
\begin{array}{l}\text { To convert U.S. to SI, } \\
\text { multiply by }\end{array}\end{array}$ & U.S. unit & SI unit & $\begin{array}{l}\text { To convert SI to U.S., } \\
\text { multiply by }\end{array}$ \\
\hline 0.4047 & $\mathrm{acre}(\mathrm{s})$ & $\mathrm{ha}$ & 2.4711 \\
0.3048 & $\mathrm{ft}$ & $\mathrm{m}$ & 3.2808 \\
2.54 & inch(es) & $\mathrm{cm}$ & 0.3937 \\
0.4536 & $\mathrm{lb}$ & $\mathrm{kg}$ & 2.2046 \\
1.1209 & $\mathrm{lb} / \mathrm{acre}$ & $\mathrm{kg} \cdot \mathrm{ha}^{-1}$ & 0.8922
\end{tabular}


third applied approximately 4 weeks after transplanting and the final third applied 4 weeks after that.

Disease control consisted of applications of Bordeaux mixture at recommended rates during conditions conducive to disease development. Based on visual evaluations, the crop was watered from an overhead centerpivot system (approximately l inch per week) as needed when soil conditions warranted.

There were four treatments in the experiment consisting of hand-weeding, wheat straw, bermudagrass hay, and compost (Longwood Plantation, Covington, Ga.). The wheat straw consisted of locally available straw harvested and baled after the grain had been harvested. The bermudagrass hay was harvested and baled bermudagrass. The compost was locally produced from feedstocks of poultry litter, cotton gin trash, and peat humus in a windrow system.

Each experimental unit consisted of four rows of onions on the prepared bed, $20 \mathrm{ft}$ long. Mulch treatments were applied immediately after onion transplanting. Each mulch treatment was applied to the plots as needed to smother weeds during the growing season. The hand-weeded plots were to be weeded as needed to maintain weed-free plots; however, relying on the grower resulted in less than optimal weed control. The experimental design was a randomized complete-block design (RCBD) with four replications.

Each plot was rated for weed pressure and the onions were harvested on 12 May 2003. Total onion yield weights and the weight of 10 bulbs were recorded for each plot. Weed pressure was rated on a $0-10$ scale with 0 indicating no weed pressure and 10 indicating extreme weed pressure $(90 \%$ to $100 \%$ plot infestation).

The following season, organically grown transplants of variety Granex EM90 were transplanted at the on-farm location in Screven County as described above on 8 Dec. 2003. The experiment was a RCBD with four replications. There were five treatments consisting of hand-weeding and mulches of compost, oat straw, bermudagrass hay, and pine needles. The oat straw was locally available baled oat straw after the grain was harvested. The pine needle mulch was locally raked and baled pine needles primarily from slash pine and longleaf pine. Mulches were ap- plied immediately after transplanting. Hand-weeding was done as needed as determined by the local grower. Cultural practices were as described above. Onions were harvested on 17 May 2004 with the total yield and total number of onions recorded for each plot. Weed control evaluation was not done in this experiment.

Vidalia Onion and Vegetable Research Center trial. A third experiment was conducted in the 2003 04 season at the VOVRC in Lyons, Ga. (lat. $32^{\circ} 11^{\prime} \mathrm{N}$, long. $82^{\circ} 17^{\prime} \mathrm{W}$ ). The experiment was a RCBD with four replications. Each plot was 20 $\mathrm{ft}$ long and transplanted as described above with variety Granex EM90 on 3 Dec. 2003. The soil type was a Tifton soil (Fine-loamy, siliceous, thermic Plinthic Paleudults). There were four treatments in this experiment consisting of hand-weeding and mulches of pine needles, wheat straw, and bermudagrass hay. Treatment mulches were applied immediately after transplanting with additional treatment mulch applied as needed to help smother weeds. Hand-weeding was also done as needed. Fertilization consisted of application of 6 tons/acre poultry litter (about $180 \mathrm{lb} /$ acre nitrogen) applied in a split application with half applied on 20 Jan. 2004 and half applied on 9 Mar. 2004. Plots were irrigated as needed from a portable pipe overhead system with approximately $\mathrm{l}$ inch of water per week. Irrigation frequency was determined by visual evaluation of soil moisture.

Plots were visually evaluated for weeds and for plant stand on 23 Feb. 2004. The weed rating scale was $0-10$ with 0 indicating no weeds and 10 indicating many weeds (90\% to $100 \%$ infestation). A rating was also used for plant stand with 1 indicating an excel- lent plant stand, while 5 indicated poor to nonexistent plant stand.

Onions were pulled, soil shaken from the roots, and laid on top of the ground on 6 May 2004 and allowed to field dry until 11 May 2004. At that time, onion tops and roots were removed and total yield was recorded for each plot. Onions were then graded into jumbo and medium size classes with smaller sizes disposed of with the culls. Jumbo onions were $\geq 3$ inches diameter and mediums were $\geq 2$ inches and $<3$ inches.

Data were subjected to analysis of variance (ANOVA) with Fisher's protected least significant difference (LSD) calculated at $P \leq 0.05$. In addition, the coefficient of variation $(\mathrm{CV})$ was calculated. The jumbo and medium data from the VOVRC during the 2003-04 season was subjected to arcsine [square root $(\mathrm{x}+0.5) / 100)$ ] to reduce the $\mathrm{CV}$ and more accurately predict differences. Means were back transformed to the original units. Plant stand and weed ratings were also transformed using square root $(\mathrm{x})$ and were also back transformed to their original units before reporting.

\section{Results}

The hand-weeded plots had the highest yields at the Screven County location during the 2002-03 growing season with $6897 \mathrm{lb} /$ acre (Table 1). This was significantly higher than wheat straw or bermudagrass hay, but was not significantly different from compost. Bermudagrass hay had the least amount of weeds with the lowest weed control rating of 2.6, which was significantly lower than all the other treatments. Finally, the largest bulb size was with compost at $2.5 \mathrm{lb} / 10$ bulbs, which was significantly greater than wheat straw or bermudagrass hay.

Table 1. Onion yield, weed control rating, and average bulb weight for handweeding and different natural mulches at Screven County, Ga., in 2002-03.

\begin{tabular}{|c|c|c|c|}
\hline Treatment & $\begin{array}{l}\text { Total yield } \\
(\text { lb/acre })^{\mathrm{z}}\end{array}$ & $\begin{array}{l}\text { Weed control rating } \\
(0-10 \text { scale })^{\mathrm{y}}\end{array}$ & $\begin{array}{c}\text { Bulb wt } \\
(1 \mathrm{lb} / 10 \text { bulbs })^{\mathrm{x}}\end{array}$ \\
\hline Hand-weeded & 6,897 & 8.6 & 2.4 \\
\hline Wheat straw & 1,851 & 8.6 & 1.5 \\
\hline Bermudagrass hay & 4,102 & 2.6 & 1.7 \\
\hline Compost & 5,009 & 9.6 & 2.5 \\
\hline Coefficient of variation & $38 \%$ & $15 \%$ & $22 \%$ \\
\hline Fisher's protected LSD ${ }^{\mathrm{w}}(P \leq 0.05)$ & 2,686 & 1.8 & 0.7 \\
\hline
\end{tabular}

${ }^{\mathrm{z}} \mathrm{l} \mathrm{lb} /$ acre $=1.1209 \mathrm{~kg} \cdot \mathrm{ha}^{-1}$

${ }^{\mathrm{y}} 0=$ excellent control; $10=$ poor control

${ }^{\mathrm{l}} \mathrm{l} \mathrm{lb}=0.4536 \mathrm{~kg}$.

"Least significant difference. 
In the second experiment at the Screven County location, the compost treatment had the greatest yield of onions at $5808 \mathrm{lb} /$ acre, which was significantly different from the bermudagrass hay, and oat straw treatments, but did not differ from the hand-weeded or pine needle treatments (Table 2). The largest number of bulbs was in the hand-weeded treatment with 17,787 bulbs/acre, which was significantly greater than oat straw and bermudagrass hay.

A third experiment at the VOVRC indicated the largest total yield with the hand-weeded treatment, which was significantly greater than wheat straw or bermudagrass hay (Table 3 ). There was no difference between the handweeded and pine needle treatments. The largest amount of medium-sized onions occurred with the hand-weeded treatment, which was significantly greater than the pine needles, wheat straw, or bermudagrass hay.

Each treatment differed significantly in plant stand rating, with the hand-weeded plot having the best plant stand followed by pine needles, bermudagrass hay, and wheat straw.

There were no differences in harvested jumbos between the treatments. In addition, there was no difference in weed rating.

\section{Discussion}

Overall, there were problems in producing onions organically in these experiments. Both the Screven County and the VOVRC sites are certified organic; therefore, we were restricted as to what chemicals and fertilizers we could employ in production. This is reflected in the relatively high cvs among some of the data collected as well as the lack of precision with some of the ANOVA results. The range of jumbo yields at the VOVRC, for example, ranged from 0 to 2831 $\mathrm{lb} / \mathrm{acre}$ with no differences between the means, indicating that the experimental error was very high. Producing onions organically is a relatively new undertaking in modern times and the sites used have only been in organic production for a short period of time with relatively low intrinsic fertility. This is reflected in the relatively low yields compared to what we routinely expect in conventional onion production. For example, the extension onion budgets are based on an average yield of $20,000 \mathrm{lb} /$ acre and it is theoreti-

Table 2. Onion yield and number with hand-weeding and different mulch types at Screven County, Ga., in 2003-04.

\begin{tabular}{lcc}
\hline Treatment & $\begin{array}{c}\text { Total yield } \\
(\text { lb } / \text { acre })^{\mathrm{z}}\end{array}$ & $\begin{array}{c}\text { Bulbs } \\
(\text { no. } / \text { plot })\end{array}$ \\
\hline Hand-weeding & 4,574 & 17,787 \\
Compost & 5,808 & 17,061 \\
Oat straw & 581 & 2,541 \\
Bermudagrass hay & 799 & 4,356 \\
Pine needles & 3,158 & 13,068 \\
Coefficient of variation & $60 \%$ & $40 \%$ \\
Fisher's protected $\operatorname{LSD}^{\mathrm{y}}(P \leq 0.05)$ & 2,759 & 6,534 \\
\hline
\end{tabular}

${ }^{2} \mathrm{l} \mathrm{lb} /$ acre $=1.1209 \mathrm{~kg} \cdot \mathrm{ha}^{-1}$

yeast significant difference.

Table 3. Total and graded yield with plant stand and weed control ratings for hand-weeded and different mulches in onions at the Vidalia Onion and Vegetable Research Center, Lyons, Ga. in 2003-04.

\begin{tabular}{|c|c|c|c|c|c|}
\hline Treatment & $\begin{array}{c}\text { Total } \\
\text { yield } \\
(1 \mathrm{~b} / \text { acre })^{\mathrm{z}}\end{array}$ & $\begin{array}{l}\text { Jumboy }^{y} \\
\text { (lb/acre) }\end{array}$ & $\begin{array}{l}\text { Medium }^{y} \\
\text { (lb/acre) }\end{array}$ & $\begin{array}{c}\text { Plant } \\
\text { stand } \\
(1-5 \text { scale })^{x}\end{array}$ & $\begin{array}{c}\text { Weed } \\
\text { control } \\
\text { rating } \\
(0-10 \text { scale })^{\mathrm{w}}\end{array}$ \\
\hline Hand-weeded & 14,665 & 2,831 & 2,432 & 1.0 & 3.6 \\
\hline Pine needles & 9,620 & 908 & 726 & 1.9 & 4.4 \\
\hline Wheat straw & 2,977 & 0 & 73 & 3.9 & 6.4 \\
\hline Bermudagrass hay & 7,078 & 1,162 & 508 & 3.2 & 4.4 \\
\hline Coefficient of variation & $41 \%$ & $59 \%$ & $39 \%$ & $17 \%$ & $27 \%$ \\
\hline $\begin{array}{l}\text { Fishers protected } \text { LSD }^{v} \\
\quad(P \leq 0.05)\end{array}$ & 5,663 & NS & 1,416 & 0.2 & NS \\
\hline
\end{tabular}

cally possible to produce two and half times this amount based on the plant spacing (Boyhan et al., 2001).

The poor results for weed control by hand-weeding in the first experiment highlights a problem with on-farm research where the researchers have to rely on the grower's timely action. Obviously, the grower got behind with this chore and clearly in an organic operation, alternatives to hand-weeding would be much appreciated.

Onions are spaced with a relatively close in-row spacing. This made it difficult to get the mulch down around the base of the plant with the mulch tending to partially cover the plants. We tried applying the mulch first and then using a pegger [four small metal wheels ( 18-inch diameter) with 2 -inch pegs every 5.5 inches to mark holes for transplanting] over the mulch to roll it flat while at the same time marking or pegging the holes for transplanting. This, we quickly realized, would not work because the workers could not see the pegged holes, so this was abandoned. This issue of the mulch partially resting on top of the plants was particularly problematic with the wheat straw, bermudagrass hay, and oat straw. These materials are known to have allelopathic affects, which we believe reduced stand and ultimately yield for those treatments, although we did not specifically test for these effects (Grimmer and Masiunas, 2005; Vasilakoglou et al., 2005; Wu et al., 2001). In addition, wheat straw in particular had wheat seed in the material, which germinated in late winter and early spring. Although the wheat is harvested before the straw is baled, there is sufficient residual seed that this became a serious weed problem. This germinating seed competed with the onions and was not sufficiently smothered by the addition of more straw.

Compost settled around the onions and therefore did not lodge in the onion tops as the wheat, oat, pine needles, or bermudagrass hay did. However, the compost, which initially appeared to smother weeds well, ultimately had very weedy plots. The compost might have acted as a 
source of nutrients, increased soil moisture, or had some other mechanism of increasing weed seed germination. This particular compost was from a very reputable operation and we have never known it to be a source of weed seed.

Pine needles appeared to have the most promise as a natural mulch. It did not exhibit any of the apparent allelopathic effects of wheat straw or bermudagrass hay, nor did it appear to encourage the growth of weeds as compost did. It did not settle well around the base of the plants because we were using slash and longleaf pine needles, which have a relatively long needle. Because this material did not settle well around the onions, there may have been a reduction in growth and ultimately yield because, we conjecture, it interfered with light interception. Light levels were not measured in and under the pine needles.

Finally, we have in the past experimented with a strawberry mulcher (WIC, Inc., Wickham, Que., Canada) that is capable of taking a square bale of straw and blowing it through an operator-controlled hose (Boyhan et al., 2002). This tends to break the straw into finer particles that settle more readily around the base of onion plants. This does not, however, alleviate the potential allelopathic effects of mulches such as wheat straw and bermudagrass hay. In addition, we used the strawberry mulcher on wellestablished, conventionally produced onions, which were much larger in size when the mulch was applied. It is unclear how such equipment would perform with newly set onion transplants. We did attempt to use this equipment with a bale of pine needles, but this proved impractical since the high resin content of the pine needles was prone to catching fire.

In conclusion, no natural mulch appeared to be very practical for weed control in organic onion production, particularly in view of current onion spacing. With all of their shortcomings, hand-weeding and the use of plastic mulches are the only current methods of weed control that have proven successful. Hand-weeding is inefficient and labor intensive while plastic mulch is nonbiodegradable and presents a disposal problem.

\section{Literature cited}

Benoit, D.L., G. Leroux, and S. Banville. 2003. Influence of carrot/onion/barley cropping sequence on the weed seed bank and field flora in an organic soil in Que., Canada. Aspects Appl. Biol. 69:69-75.

Bond, W., H.C. Moore, R.J. Atkinson, J.R. Bevan, and M.E.K. Lennartsson. 1998. Changes in the weed seedbank following different weeding treatments in drilled salad onion and carrot crops grown in organic and conventional systems. Biol. Agr. Hort. $16: 203-215$.

Bourdôt, G.W., G.A. Hurrell, and D.J. Saville. 2004. Estimating when to weed an organically-grown onion crop. 14th Austral. Weeds Conf., Weed Mgt.: Balancing people, planet, profit. p.182-186.

Boyhan, G.E., D.M. Granberry, and W.T. Kelley. 2001. Onion production guide. Univ. of Georgia Bul. 198.

Boyhan, G.E. and R.L. Torrance. 2002. Vidalia onions-Sweet onion production in southeastern Georgia. HortTechnology 12:196-202.

Boyhan, G., R. Torrance, J. Cook, and R. Hill. 2002. Effect of a strawberry mulcher on Vidalia onion production. Georgia Onion 2002 Res.-Ext. Rpt. Coop. Res.-Ext. Publ. No. 3-2002:15-18.

Brewster, J.L. 1994. Onions and other vegetable alliums. CAB Intl., Wallingford, U.K.

Culpepper, A.S. 2004. Commercial vegetables-Weed control, p. 269-324. In: P. Guillebeau (ed.). 2004 Georgia pest management handbook. Univ. of Georgia, Athens.
Gergon, E.B., S.A. Miller, R.G. Davide, O.S. Opina, and S.R. Obien. 2001. Evaluation of cultural practices (surface burning, deep ploughing, organic amendments) for management of rice root-knot nematode in rice-onion cropping system and their effect on onion (Allium cepa L.) yield. Intl. J. Pest Mgt. 47:265-272.

Grimmer, O.P. and J.B. Masiunas. 2005. The weed control potential of oat cultivars. HortTechnology 15:140-144.

Hellwig, A. and E. Buczak. 1973. Effects of grass/legume mixtures in a vegetable crop rotation on vegetable yields and soil properties. Biuletyn Warzywniczy 15:71-103.

Juncker, E., J.M. Thomas, and S. Begat. 1993. Influence of several non-chemical weeding practices on organic onion yield and yield components. First year results. Maitrise des adventices par voie non chimique. Communications de la quatrieme conference internationale I.F.O.A.M. (Intl. Federation of Organic Agr. Movements). p. 369-373.

Leroux, G.D., D.L. Benôit, and S. Banville. 1996. Effect of crop rotations on weed control, Bidenscernua and Erigeron canadensis populations, and carrot yields in organic soils. Crop Protection 15:171-178.

Mihelic, R. and M. Jakse. 2001. Nitrogen dynamics in intensive vegetable crop rotation influenced by organic fertilisation. Acta Hort. 563:163-170.

Ozer, N., N.D. Koycu, M. Mirik, H. Soran, and D. Boyraz. 2002. Effect of some organic amendments on onion bulb rot. Phytoparasitica 30:429-433.

Piazza, C., R. Reggiani, and M.C. Cera. 2003. Varietal experiments on organically grown onions. Sementi Elette 49:39-41.

Vasilakoglou, I., K. Dhima, and I. Eleftherohorinos. 2005. Allelopathic potential of bermudagrass and johnsongrass and their interference with cotton and corn. Agron. J. 97:303-313.

Wu, H., J. Pratley, D. Lemerle, and T. Haig. 2001. Allelopathy in wheat (Triticum aestivum). Ann. Appl. Biol. 139:1-9. 